\title{
Factors Influencing Clients' Commitment to Sustainable Construction Practices
}

\author{
Peter Uchenna Okoye
}

Department of Building, Nnamdi Azikiwe University, Awka 420007, Nigeria

Corresponding Author Email: pu.okoye@ unizik.edu.ng

https://doi.org/10.18280/ijsdp.160104

Received: 25 November 2020

Accepted: 8 February 2021

\section{Keywords: \\ client, commitment, construction practices, construction project,} sustainable construction

\begin{abstract}
The success of every construction projects largely depends on the level of commitment of the clients. This study examined the factors influencing the level of clients' commitment to sustainable construction practices in Nigeria. A questionnaire survey was use to collect data from the public and private construction clients on the level of influence of 16 factors extracted from the literature. A total of 182 valid questionnaires were used for analysis. The result revealed that nine factors with weighted average (W) $0.8 \leq \mathrm{W} \leq 1$ have a high level of influence, whereas seven factors with $0.6 \leq \mathrm{W} \leq 0.8$ have a high-medium level of influence on the clients' commitment. However, the five most influential factors were: client knowledge and awareness, Cost implication and mechanism of financial involvement, economic value and return on investment, end-user/client perception and preference, and health and safety implications. The result further revealed that there is significant difference on how these factors influence the level of commitment of sustainable construction practices of the public and private clients. The study suggested that the disparity was due to the differences in the level of knowledge, awareness, involvement and commitment of the public and private clients to sustainable construction concept. Hence, it is important to optimize the level of knowledge and awareness of the clients, about the cost, benefits/profits, and health and safety implications of sustainable construction practices so as to promote the level of client's commitment to sustainable construction practices. It recommended for adequate client involvement throughout the sustainable construction life cycle and a sustained awareness campaign, championed by relevant government agencies and professional organizations through different public programs so as to increase the clients' commitment and desirability to demand for more sustainable construction projects.
\end{abstract}

\section{INTRODUCTION}

The continuous growth of construction industry and the adoption of conventional approach to construction practices in Nigeria have affected the environment and the wellbeing of the populace negatively [1]. These growing concerns have constantly kept the industry under pressure since the issues of environmental destruction from construction activities appear regularly in all aspects of human discussion [2]. As a result, the government and private sectors are becoming more proactive in minimizing this problem without restraining the need for development [3]. Adopting sustainable construction practices therefore, minimizes the overall environmental impact of the built asset throughout its whole life [4]. Thus, there is need for the construction industry to modernize the traditional construction practices of the industry towards adopting a new and more sustainable approach that would have a little or no negative impact on the environment and the wellbeing of the people [5]. This new approach would integrate the social and environmental benefits into what has been traditionally considered as the primary business driver: profit maximization [5]. According to Koko and Bello [1], sustainable construction practice is the new approach in construction industry that strives to achieve sustainability.

Sustainable construction practice therefore, depicts the construction sector's response to sustainability which is borne out of man's concern for increasing consumption patterns in the mist of earth's limited carrying capacity to sustain lives [6]. Sustainable construction focuses on how construction projects can preserve the environment and have an impact on the social and economic welfare of the community [7]. It is the utilization of sustainable materials and technologies in the design, construction and operation of construction projects. In practical term, a sustainable building uses less water, optimizes energy efficiency, conserves natural resources, generates less waste, provides healthier spaces for occupants as well as reducing building impact on human health and the environment during the building's lifecycle as compared to conventional buildings $[8,9]$. It can create many benefits to their developers, owners, and occupants such as improved financial returns and occupant comfort and wellbeing [10].

Unfortunately, a lot of challenges and uncertainties are restraining the implementation of sustainable construction practice especially in the developing countries [1, 3, 11-18]. Successful implementation of sustainable construction principles requires the commitment of all parties who are involved in construction projects [7]. The success of sustainability in the construction industry depends on the decisions of the key actors in the construction process, including owners, managers, designers, firms, governments, etc. [19]. However, amongst all parties involved with the delivery of construction project, the client organization 
remains the only constant actor throughout the whole project lifecycle [20]. Therefore, the decision made by the clients influences the overall project performance [21]. These decisions influence the attitudes, behaviors and procedures of other parties that must be addressed, so as to achieve sustainability of the built environment [22]. Additionally, the level of awareness as well as the adoption of sustainable construction practices by the clients play an important role in achieving sustainability in the construction processes [23]

Although each of the key supply chain stakeholders (developers, architects/consultants, contractors and suppliers) and other extended stakeholders (regulatory bodies, end users and non-government organizations) have a role to play in delivering sustainable construction project [24], the role of the clients in the success of sustainable construction projects is fundamental [22, 25-27]. As a single most important driver needed to ensure that a building is more sustainable or environmentally-responsible, the client's decisions have an overriding influence in the level of implementation of sustainable construction practices [20]. Specifically, a responsible client expresses his/her sustainability aims in a policy statement which can then act as a stimulus for a cascade of sustainability action plans for social, economic and environmental issues including funding, equal opportunities, health and safety, community relations, energy and water use, biodiversity, air and water quality, waste, etc. For clients, sustainable construction means: Lower whole life costs relating to their building, better relationships with local communities, a more pleasant and healthy indoor environment for the building occupants, reduced environmental impact through both construction and operation and improved corporate image [28]. In this case, clients are well placed to play a key role in delivering more sustainable construction, because they are at, or near the top of the construction supply chain [28]. Understanding the factors influencing the clients' decisions towards sustainable construction practices is therefore, germane [20].

Furthermore, in this era of innovative changes in construction processes, the construction projects are expected to satisfy the economic objectives of the clients while preserving the natural environment and protecting the social wellbeing of the occupants [29]. However, different factors are militating against the construction industry's sustainability initiatives [30-36]. The extant literature shows that most of these factors are client-related [21, 37-39]. Although these facts subsist, studies have not provided a practical means of dealing with the factors that affect the implementation of sustainable construction with respect to clients [40].

For example, Gunduz and Almuajebh [37] identified clients-related factors such as influence of client/client's representative and mechanism of financial payments among the top critical success factors for sustainable construction project management. Hwang et al. [38] revealed that the client related barriers such as perceived higher initial capital costs, uncertain trade-off between environmental and financial benefits, and lack of government support have the most significant impacts on three project objectives of cost, schedule and quality. These studies were not specific to the factors influencing the clients' commitment to sustainable construction practices, instead they considered the general factors affecting the success of sustainable construction projects.

Elforgani and Rahmat [21] studied the key clients' attributes influencing sustainable design performance of building projects. They identified seven client qualities, including client communication with design team, client involvement during process, client ability to coordinate of design process, client organization commitment to green, commitment in financing green design, knowledge on green design, and experience on green design. However, the study revealed that the rate at which client exhibit these qualities towards sustainable building practice was either moderate, low or very low. Although, some factors were identified, the study failed to determine how they influence the commitment of the clients, rather it investigated their level of application. Abisuga and Oyekanmi [19] revealed that lack of awareness and knowledge, cost and economic viability, passive culture or norm, goal and objectives, and local authority and government were among the top factors militating against the sustainable construction practice. However, this study ignored the role of client in the achievement of sustainable construction.

On the other hands, Sourani and Sohail [41] identified 41 factors that influence the UK public clients to address sustainable construction in developing procurement strategies These factors were categorized into knowledge and perception factors, organizational and management factors, political and regulative factors, logistical factors, contractual factors, instrumental factors, strategic factors and financial factors. Berawi et al. [42] investigated how the level of knowledge, economic capability, environmental conditions, and regional policies affect the building developers and owners' adaptation of sustainability concepts in building construction. The study revealed that the level of knowledge of building developers and building owners affects the ability of building management to achieve a sustainable concept. While Sourani and Sohail [41] concentrated on the UK public clients only, Berawi et al. [42] limited their studies to few factors. Table 1 shows the literature extract of the factors influencing the clients' commitment to sustainable construction practices.

Nevertheless, since the client is a financier or promoter of the construction project, who provides information concerning the business mission and the goal and context of the organizational structure as well as the overall aim of the project [21], the roles of client in ensuring sustainability in the construction practices are very critical. Available literature focusing on the factors affecting the roles of clients in the implementation of sustainable construction practices are even scantier and lop-sided [43]. Therefore, if the perception of the client is that the implementation of sustainable construction practices is the sole role of the government, this becomes more worrisome and may hinder a transition from conventional construction methods and processes to a more sustainable one [44]. Hence, this study is aimed at examining the factors influencing clients' commitment to sustainable construction practices in Nigeria with a view to providing a practical guide to promoting the implementation of sustainable construction practices. This study specifically looks into the dynamics of construction clients and addresses the following questions:

1. What contextual factors and the level of influence do they have on the construction client's commitment to sustainable construction practices?

2. How do these factors influence the public and private construction clients' level of commitment to sustainable construction practices?

Understanding these contextual factors and their level of influence on the clients' commitment to sustainable construction practices is very important. It is also important to evaluate how these factors influence different categories of 
construction clients. Thus, this study hypothesizes that:

\subsection{Hypothesis}

Ho: There is no significant difference between how the public and private construction clients' level of commitment to sustainable construction practices is being influence Table 1. Literature summary of the factors influencing clients' commitment in the implementation of sustainable construction practices.

Table 1. Literature summary of the factors influencing client's commitment in the implementation of sustainable construction practices

\begin{tabular}{lcc} 
Code & Sources & Factors \\
CCP1 & {$[12,21,39,41,45]$} & End-user/client perception and preference \\
CCP2 & {$[11,12,19,21,23,41,42,46-50]$} & Client knowledge and awareness \\
CCP3 & {$[41,51-53]$} & Level of stress and uncertainty \\
CCP4 & {$[19,51,54,55]$} & Economic value and return on investment \\
CCP5 & {$[19,21,23,12,54,56]$} & Cost implication and mechanism of financial involvement \\
CCP6 & {$[57-63]$} & Health and safety implications \\
CCP7 & {$[21,34,41,46,64]$} & Availability of resources \\
CCP8 & {$[41,54,56,65]$} & Prevailing economic and political condition \\
CCP9 & {$[66-69]$} & Existing competitors \\
CCP10 & {$[19,21,51,55,70]$} & Existing trends and traditions \\
CCP11 & {$[14,19,21,23,46,48,54,68,71,72]$} & Level of involvement, interest and demand \\
CCP12 & {$[32,38,52]$} & Compatibility with client objectives \\
CCP13 & {$[41,43,60,73-75]$} & Impact on environment \\
CCP14 & {$[11,23,33,37,42,46,48,51,54]$} & Existing laws and regulations \\
CCP15 & {$[19,46,48,51]$} & Cultural resistance to change \\
CCP16 & {$[36,40,42,51,71,76]$} & Availability of incentives and motivation \\
\hline
\end{tabular}

\section{METHODOLOGY}

This study adopted a survey research method to explore the opinions of the building construction clients on the factors influencing their commitments to sustainable construction practices. Prior to the actual survey, contacts and information of the prospective respondents were established through the help of research assistants in the five states of the South-East Nigeria. Consents were also sought and obtained from the relevant persons.

During the survey, 400 copies of structured questionnaires were distributed to the public and private building project clients earlier identified by hand and e-mail. After series of reminder, 182 completed and valid questionnaires were retrieved and used in the analysis. The questionnaires were distributed to the respondents (client's representatives) at construction sites for private/public projects, or at the Ministries' offices that are in charge of building projects for public projects. For the purpose of this study, public clients undertake construction projects using public money either from local, state or federal sources [77], whereas private clients fund their own projects either through internal (personal income) or external (financial institutions) means [78].

The questionnaire was made up of two sections. Section 1 captures the respondents' demographic data. Section 2 comprises 16 variables extracted from the literature as shown in Table 1 and measuring the factors influencing the clients' commitment to sustainable construction practices. Although there are many factors influencing the implementation of sustainable construction, through an in-depth review, 16 factors that specifically influence the clients' decisions and roles in the construction project were selected and used in this study. Any variable that appears in up to two references was included in the questionnaire. The assessment measure was matched to the aim of the study. Further assessment was carried out by the researchers for troublesome wording and other difficulties. Subsequently, two academic experts in the field of study were engaged to assess the adequacy and suitability of the questionnaire and for expert evaluation. The input of these experts was reflected in the modified questionnaire which was used in the final survey. The respondents were asked to rate the factors on a 5-point Likert Scale. Where $1=$ Very insignificant, 2=Insignificant, 3=Neutral, 4=Significant, 5=Very Significant.

The survey data were descriptively and quantitatively analyzed. The internal consistency of the survey instrument was checked using the Cronbach's alpha $(\alpha)$. Cronbach's alpha $>0.6$ was adopted as reliable and acceptable for the data collection instrument in this study $[79,80]$. In this study, the Cronbach's alpha as shown in Table 2 is 0.726 which is greater than 0.60. This implies that the survey instrument used for this study is reliable, and can be used as instrument for data collection. It also satisfied the test of construct reliability and internal consistency.

Table 2. Result of reliability test

\begin{tabular}{ccc}
\hline \multicolumn{3}{c}{ Reliability Statistics } \\
\hline Cronbach's & Cronbach's Alpha Based on & N of Items \\
Alpha & Standardized Items & \\
0.726 & 0.718 & 16 \\
\hline
\end{tabular}

The Mean Score Index (MSI) was computed to determine the score of each factor on the clients' commitment in the implementation of sustainable construction practices. MSI was computed using Eq. (1).

$$
M S I=\frac{\sum f_{i} x_{i}}{N}
$$

where, MSI = mean score index; $f=$ frequency of responses to each rating scale (integer value $(i)$ between 1 and 5), $x=$ score or rating given to each variable by the respondents; and $N=$ total number of the respondents selecting a rating equal to $i$.

A weighted average (W) was then computed for each of the 
factors using Eq. (2) to determine the level of influence.

$$
W=\frac{M S I}{A}
$$

where, $A=$ the highest rating (in this case $=5$ ).

Based on the weighted average (W), the level of influence of each of each factor was established and ranked. Five levels of influence were transformed in accordance with [72]. Where high $(\mathrm{H})=(0.8 \leq \mathrm{W} \leq 1)$, high-medium $(\mathrm{H}-\mathrm{M})=(0.6 \leq \mathrm{W} \leq 0.8)$, medium $(\mathrm{M})=(0.4 \leq \mathrm{W} \leq 0.6)$, medium-low $(\mathrm{M}-\mathrm{L})=$ $(0.2 \leq \mathrm{W} \leq 0.4)$ and low $(\mathrm{L})=(0 \leq \mathrm{W} \leq 0.2)$.

Furthermore, the Mann-Whitney $U$ test statistic was conducted to determine the significant difference in the ranking between the opinions of the public and private clients on the factors influencing their commitment in the implementation of sustainable construction practices. SPSS Version 22 was deployed to run the entire statistical analysis.

\section{RESULT}

\subsection{Background information of the respondents}

Table 3 shows the basic information of the respondents. As expected the respondents were made up of public and private building projects clients or their representatives. The public clients were mainly represented by the consultants and staff in the ministries and agencies responsible for construction projects and who serve as supervisors or monitoring teams. Some private clients were self-represented while other have supervisors and caretakers who oversee the daily activities on the project sites. Interestingly, most $(87.91 \%)$ of the clients or their representatives had construction experience. Similarly, most $(81.25 \%)$ of those with construction experience have had at least five years' construction experience. Based on the information provided, it shows that the respondents were suitable for the study.
Table 3. Respondents' background information

\begin{tabular}{cc}
\hline Variable & Responses (\%) \\
Category of Client & \\
Public & 43.41 \\
Private & 56.59 \\
Educational Level & \\
Primary & 15.38 \\
Secondary & 21.98 \\
Higher institution & 40.66 \\
Post graduate & 19.78 \\
Others & 2.20 \\
Job Role & \\
Consultant & 23.08 \\
Supervisor & 47.80 \\
Caretaker/owner & 20.88 \\
Others & 8.24 \\
Construction Experience & \\
Yes & 87.91 \\
No & 12.09 \\
If "Yes" Years of Experience & 5.00 \\
Less than 1 year & 13.75 \\
1-5 years & 51.25 \\
6-10 years & 30.00 \\
Above 10 years & \\
\hline
\end{tabular}

\subsection{Analysis of factors influencing clients' commitment in the sustainable construction practices}

Table 4 shows the result of MSI, weighted average and level of influence of the 16 factors affecting the commitment of client to sustainable construction practices. The MSI result revealed that the all the factors scored above 3.00 in both the public and private clients' ratings with an MSI range of 3.624.94 for public clients and 3.22-4.99 for private clients. Although the result suggested that all the factors are significantly influencing client's commitment to sustainable construction practices, the higher the MSI, the greater the level of influence.

Table 4. Result of the MSI, weighted average and level of influence of factors affecting the clients' commitment in the sustainable construction practices

\begin{tabular}{|c|c|c|c|c|c|c|c|c|}
\hline \multirow[t]{2}{*}{ Code } & \multirow{2}{*}{$\begin{array}{c}\text { Factors } \\
(\text { Cronbach's Alpha }=.726)\end{array}$} & \multicolumn{2}{|c|}{ Public Client } & \multicolumn{2}{|c|}{ Private Client } & \multirow[t]{2}{*}{$\mathbf{W}$} & \multirow{2}{*}{$\begin{array}{c}\text { Level of } \\
\text { Influence }\end{array}$} & \multirow{2}{*}{$\begin{array}{c}\text { Factor } \\
\text { Ranking }\end{array}$} \\
\hline & & $\mathbf{N}$ & MSI & $\mathbf{N}$ & MSI & & & \\
\hline CCP1 & End-user/client perception and preference & 69 & 4.3333 & 113 & 4.3717 & 0.8714 & $\mathrm{H}$ & 4 \\
\hline CCP2 & Economic value and return on investment & 69 & 4.6087 & 113 & 4.6195 & 0.9231 & $\mathrm{H}$ & 3 \\
\hline CCP3 & Level of stress and uncertainty & 69 & 3.8261 & 113 & 3.7522 & 0.7560 & H-M & 12 \\
\hline CCP4 & Client knowledge and awareness & 69 & 4.9420 & 113 & 4.9912 & 0.9945 & $\mathrm{H}$ & 1 \\
\hline CCP5 & Cost implication and mechanism of financial involvement & 69 & 4.7826 & 113 & 4.7345 & 0.9505 & $\mathrm{H}$ & 2 \\
\hline ССР6 & Health and safety implications & 69 & 4.3188 & 113 & 4.2212 & 0.8516 & $\mathrm{H}$ & 5 \\
\hline CCP7 & Availability of resources & 69 & 3.8406 & 113 & 4.2478 & 0.8187 & $\mathrm{H}$ & 9 \\
\hline ССР8 & Prevailing economic and political condition & 69 & 4.2174 & 113 & 4.0973 & 0.8286 & $\mathrm{H}$ & 8 \\
\hline ССР9 & Existing competitors & 69 & 3.6232 & 113 & 3.6814 & 0.7319 & $\mathrm{H}-\mathrm{M}$ & 15 \\
\hline CCP10 & Existing trends and traditions & 69 & 4.6087 & 113 & 3.7611 & 0.8165 & $\mathrm{H}-\mathrm{M}$ & 10 \\
\hline CCP11 & Level of involvement, interest and demand & 69 & 4.4203 & 113 & 4.0354 & 0.8363 & $\mathrm{H}$ & 6 \\
\hline CCP12 & Compatibility with client objectives & 69 & 4.3188 & 113 & 3.6460 & 0.7802 & H-M & 11 \\
\hline CCP13 & Impact on environment & 69 & 3.8551 & 113 & 3.2212 & 0.6923 & $\mathrm{H}-\mathrm{M}$ & 16 \\
\hline CCP14 & Existing laws and regulations & 69 & 4.2609 & 113 & 3.4690 & 0.7538 & $\mathrm{H}-\mathrm{M}$ & 13 \\
\hline CCP15 & Cultural resistance to change & 69 & 4.2464 & 113 & 3.4159 & 0.7462 & $\mathrm{H}-\mathrm{M}$ & 14 \\
\hline CCP16 & Availability of incentives and motivation & 69 & 4.4203 & 113 & 3.9912 & 0.8308 & $\mathrm{H}$ & 7 \\
\hline
\end{tabular}

Although all the factors with $\mathrm{W} \geq 0.8$ signify that they are critical factors, the five most influential factors are: Client knowledge and awareness (0.99), Cost implication and mechanism of financial involvement $(0.95)$, economic value and return on investment (0.92), end-user/client perception and preference (0.87), and health and safety implications (0.85). This implies that the clients should be well-informed and educated about the cost and benefits of the sustainable construction including its health and safety implications and profit on investments so as to be able to make a good decision 
on which option(s) is to be adopted. The result further suggested that the clients are not very much aware of the whole concept of sustainable construction. As a result, it is rational for one to resist what he/she is does not have a full knowledge of due to uncertainties. This therefore, underscores the importance of knowledge and awareness of sustainable construction practices among the clients. Overall, this result suggested that the clients are more reactive to issues concerning social and economic sustainability.

In order to ascertain if the factors are influencing the clients in the same way, the significant difference in the ranking giving by each respondents in the two groups (public and private) was determined using a Mann-Whitney U test to test the hypothesis 1 . The result is presented in Tables 5 and 6.

Table 5. Result of Mann-Whitney U test

\begin{tabular}{cc}
\hline \multicolumn{1}{c}{ Test Statistics $^{\mathrm{a}}$} & Client \\
\hline Mann-Whitney U & $2.004 \mathrm{E} 3$ \\
Wilcoxon W & $8.445 \mathrm{E} 3$ \\
$\mathrm{Z}$ & -5.504 \\
Asymp. Sig. (2-tailed) & .000 \\
Exact Sig. (2-tailed) & .000 \\
Exact Sig. (1-tailed) & .000 \\
Point Probability & .000 \\
\hline a. Grouping Variable: Category & \\
\hline
\end{tabular}

Table 6. Result of mean rank from Mann-Whitney U test

\begin{tabular}{ccccc}
\hline & \multicolumn{3}{c}{ Ranks } & \\
& Category & N & Mean Rank & Sum of Ranks \\
\hline Client & public & 69 & 118.96 & 8208.00 \\
& private & 113 & 74.73 & 8445.00 \\
& Total & 182 & & \\
\hline
\end{tabular}

\subsection{Test of hypothesis}

The result of the Mann-Whitney $U$ test in Table 5 revealed that $\mathrm{U}=2.004 \mathrm{E} 3, \mathrm{Z}=-5.504$, and $p=.000<.05$ ). This indicates that the null hypothesis is rejected. It implies that there is significant difference between the ranking of the public and private sector clients on the factors influencing their commitments to sustainable construction practices. It further implies that the way in which the factors influence the commitment of the clients to sustainable construction practices differs, due to their different representations, priorities, objectives and aspirations.

Although the result of Table 4 suggested that all the factors show significant influence on the clients' commitment to sustainable construction practices, the Mann-Whitney U result (see Table 5) suggested that the clients have different levels of understand of the concept of sustainable construction practices which informed their judgements and the way they perceived the effect of the factors on their level of commitment. The rating in Table 4 alluded to the fact that the public sector clients are more informed than the private sector clients. The fact that those representing the public clients were consultants and staff in the ministries and agencies responsible for construction projects, and could be more informed than the private sector clients due to their level of education, exposure and experience in construction practices; might be one of the reasons for this difference. Besides, the representatives of the public clients could be talking from the public interest perspective, whereas those of the private clients were projecting their personal interests. That is to say that the public client represents the general wellbeing of the people by concentrating more on the provision of social services and projects that will lead to social sustainability. On the other hand, the private client clings to the primary business objective of profit maximization which entails economic sustainability.

Since there is significant difference between how the clients are affected by the factors in their commitment to sustainable construction practices as shown by the ranking of the two categories of clients, it is desirable to compare the mean of the distribution of the two groups of the respondents to confirmed the statistical significance of the difference in ranking of the groups. The result of the comparison is presented in Table 6 .

The result of Table 6 therefore, indicated that public clients ( $N=69)$ has a larger mean rank (118.96) than the private clients $(\mathrm{N}=113)$ with mean rank (74.73) and tends to take larger values. The presence of larger values for the public clients group suggested the existence of statistical significant difference between the two groups and also confirmed the differences in the understanding and rating of the factors by the clients. It also indicated the different meanings attached to sustainability goals and level of efforts towards achieving the goals in the construction practices by the clients. However, to determine the magnitude of the difference between the two groups, an effect size was calculated. The effect size $(r)$ was calculated by dividing the absolute (positive) standardized test statistic $z$ by the square roof of the number of groups $(\mathrm{N})$ as represented in Eq. (3). Thus,

$$
r=\frac{z}{\sqrt{N}}
$$

where, $\mathrm{z}=5.504$ and $\mathrm{N}=182$.

$$
\text { Therefore, } r=\frac{5.504}{\sqrt{182}}=0.408
$$

Based on the Cohen's classification of effect sizes, where $0.1=$ small effect, $0.3=$ moderate effect and $\geq 0.5=$ large effect, the effect size in this study is $(0.408)$ which indicated moderate effects. This result then suggested that the difference in the ranking between public and private clients has a moderate effect due reasons adduced earlier. It further implies that the private sector clients need to be properly educated about the cost, profitability, values and health and safety implications of sustainable construction practices so as to be on the same level of understanding with the public sector clients and to take a proper decision about implementing sustainable construction practices in their future projects.

\section{DISCUSSION}

From the foregoing results, this study demonstrated the importance of certain factors that influence the commitment of public and private sector clients to sustainable construction practices. From the 16 variables representing the factors influencing the clients' commitment to sustainable construction practices as shown in Table 4, the result through the MSI shows that all the factors have potential to influence the commitment of both public and private sector clients to sustainable construction practices. From the measurement scales, all the factors on average score more than 3.50 for MSI and 0.6 for level of influence. However, the study revealed that some of these factors are critical to the extent that they have 
high influence on the clients' commitment which inadvertently influence their decisions and actions towards sustainable construction practices. In other words, the high influence factors need not to be ignored else clients would be skeptical to commit to any sustainable construction initiative Specifically, nine factors were identified as critical factors with high influence on the clients' commitments and decisions. Among the top critical factors are: Client knowledge and awareness, cost implication and mechanism of financial involvement, economic value and return on investment, enduser/client perception and preference, and health and safety implications of sustainable construction practices. This therefore, highlighted the importance of clients' knowledge and understanding of the concept of sustainable construction, which forms their perception, sense of value, financial plan and commitment, sense of safety and preferences. The study argues that both public and private clients should be wellinformed and educated about the cost and benefits of sustainable construction practice including its health and safety implications, and profit on investments so as to be able to take good decisions on which option(s) to be adopted. This position aligns with [72], who posited that lack of practical understanding of sustainability hampers the effective implementation of the concept in the construction process. It also supports the submission of [76] which suggested encouragement of public and private clients to know more about sustainable construction concept so as to promote the demands and supply of sustainable construction projects.

The study further revealed that though the factors significantly influence the clients, there is disparity on how these factors influence the government as the public sector client and private construction clients (see Tables 5 and 6). Since the two categories of clients have different priorities, focus, objectives and preferences, it is logical that this difference in ranking is observed. Practically, government as the single public sector client is focusing more on achieving social sustainability through the provision of infrastructural projects; and environmental sustainability through the enactment of laws to protect the environment from the impacts of construction activities. Whereas, the private clients are concerned with the economic gains from their investments (economic sustainability). On this ground, this study avers that the differences in the level of knowledge and understanding of the cost and benefits of sustainable construction concepts between the public and private clients lead to differences in preferences and skepticisms between the clients. The study further avers that lack of knowledge and uncertainties could becloud one's sense of judgement. That is to say that different factors have different level of influence on the different category of clients. These differences shaped the clients' dispositions and sense of direction and commitments to sustainable construction practices

Undoubtedly, the result of this study pointed to the reason why Nigerian clients both public and private are still dragging their feet to change from the traditional system of construction practices to a more modern and sustainable one. It then makes case for a sustained awareness campaign to increase the knowledge and awareness of the clients on the tenets, concept, cost and benefits of sustainable construction through education and training. As indicated in this study, the disparity in the ranking due to difference in the level of knowledge and understanding between the public and private clients, needs to be closed through increased awareness campaigns especially for the private clients as suggested by Chan et al. [13] so as to increase the clients' demand for sustainable construction projects.

The criticality of nine factors suggested the level of impact of these factors to client's commitment. This corroborates Abisuga and Oyekanmi [19], Elforgani and Rahmat [21], and Berawi et al. [42] who identified client knowledge and awareness, cost and economic viability, client involvement, environmental conditions, and local authority and government among the top client-related factors influencing sustainable construction practices. Contrarily, factors such as client objectives, culture and norms were found to have highmedium influence as against Abisuga and Oyekanmi [19] who found them as top influencing factors. The importance of client's involvement, mechanism of financial involvement, environmental and financial benefits of the practice was also highlighted from the result of this study and supported by Elforgani and Rahmat [21], Gunduz and Almuajebh [37], Hwang et al. [38], and Schweiger et al. [50]. Similarly, this study supports the result of Sourani and Sohail [41] who identified knowledge and perception factors, political and regulative factors, and financial factors as factors that influence the public clients to address sustainable construction.

Having seen from the result of this study that clients' level of knowledge and awareness of sustainable construction concepts, cost and mechanism of financial involvement, expected economic value and return on investment, enduser/client perception and preference, health and safety implications of sustainable construction practices, etc. are very important factors towards implementation of sustainable construction practices, this study argues that sustainable construction practices cannot be successfully operationalized if these factors are not properly considered throughout the life cycle of a construction project.

\section{CONCLUSION}

Different approaches and efforts have been proposed towards overcoming the challenges of implementing sustainable construction practices. Admittedly, the barrier to successful sustainable construction practices are many and multi-faceted. But as a critical stakeholder in the process of delivering sustainability goals in the construction project, the role of clients and factors affecting its optimization are very important, and thus, need to be appraised. This study therefore, examined the factors affecting the clients' commitment to sustainable construction practices.

The study has identified 16 factors with potential influence to clients' commitment to sustainable construction practices. Out of these factors, the study revealed that nine showed critical and high level of influence on the clients' commitment, whereas seven show high-medium level of influence. However, the five most influential factors are: client knowledge and awareness, Cost implication and mechanism of financial involvement, economic value and return on investment, end-user/client perception and preference, and health and safety implications. The study further revealed that there is significant difference in the ranking of the public and private clients on the factors influencing their commitment due to difference in their level of knowledge and awareness about sustainable construction concept. This demonstrated the importance of knowledge and awareness about the cost and benefits of sustainable construction practices among construction clients. It implies that with adequate knowledge 
and awareness about the cost, benefits/profits, health and safety implications, the clients would be well informed and armed with requisite information to take decisions regarding adopting sustainable construction practices.

The strength of this study lies in the fact that a critical stakeholder (client) whose interest and influence in the overall success of construction projects is very impactful was studied. While most studies were silent on the role of clients and factors affecting the clients' commitment to sustainable construction practices, this study has explored into the area and found that certain factors are critical to both public and private clients' commitment to sustainable construction practices. It highlighted the need to increase the information available to the clients on the cost and benefits of sustainable construction practices so as to increase the clients' desire to adopt sustainable construction concepts in their future construction projects.

Considering the pivotal role of client in the overall success of construction projects, this study argues that integrating client into the process of achieving a sustainable construction would determine the level of client's commitment and nature of decisions taken by the client. Practically, if the level of client's knowledge, involvement, perception, preferences, etc. are not factored into every process leading to sustainable construction, there is tendency that the project would fail to achieve its optimal goal. Ordinarily, clients wouldn't have had sufficient knowledge if not adequately integrated into the whole process of sustainable construction life cycle. Besides, the overriding influence of the client on other project teams would have a consequential effect on the success of sustainable construction project.

However, since this study adopted only a small number of respondents (sample size), generalization of the result of this study might be affected. Notwithstanding, the results of this study indicates that those factors could be the reason for clients' resistance to changing from conventional (traditional) procurement system to a more sustainable integrated system in Nigeria. Furthermore, the study has added to the growing body of knowledge in the areas of client organization and sustainable construction. More importantly, if the process of increasing the client's knowledge and getting them involved in the sustainable construction project is optimized as suggested by this study, it would increase the client's commitment to sustainable construction practices. Thus, this study has contributed to the promotion of sustainable construction practices by improving and advocating customer commitment.

Finally, this study recommends that government agencies and professional organizations should champion the awareness campaign especially among the private clients through different public programs. This would increase the knowledge level of the clients and desirability to demand for sustainable construction projects and change the current contractual system that lacks flexibility to facilitate a productbased value expected of a sustainable construction.

\section{REFERENCES}

[1] Koko, A.F., Bello, M. (2020). Exploring the factors hindering the use of green architecture in Nigeria. ZeroEnergy Buildings - New Approaches and Technologies. http://dx.doi.org/10.5772/intechopen.92403
[2] Idris, N.H., Ismail, Z., Hashim, H. (2015). Towards a framework for promoting sustainable construction in Malaysia. Jurnal Teknologi, 76(1): 303-311. https://doi.org/10.11113/jt.v76.2674

[3] Rafindadi, A.D., Mikić, M., Kovaćić, I., Cekić, Z. (2014). Global perception of sustainable construction project risks. Procedia - Social and Behavioral Sciences, 119: 456-465. https://doi.org/10.1016/j.sbspro.2014.03.051

[4] Opoku, A., Ahmed, V. (2014). Embracing sustainability practices in UK construction organizations: Challenges facing intra-organizational leadership. Built Environment Project and Asset Management, 4(1): 90107. https://doi.org/10.1108/BEPAM-02-2013-0001

[5] Geach, I. (2016). Investigating the role of sustainability in contractor selection and evaluation. Sustainability Scholarship 2015/2016. https://www.ciob.org/sites/default/files/View\%20Inga\%

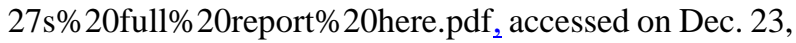
2020.

[6] Dania, A.A. (2016). Sustainable construction at the firm level: Case studies from Nigeria. PhD Dissertation, School of Construction Management and Engineering, University of Reading. http://centaur.reading.ac.uk/72754/1/18028935_Dania_t hesis.pdf, accessed on Dec. 23, 2020.

[7] Willar, D., Waney, E.V.Y., Pangemanan, D.D.G., Mait, R.E.G. (2020). Sustainable construction practices in the execution of infrastructure projects: The extent of implementation. Smart and Sustainable Built Environment. https://doi.org/10.1108/SASBE-07-20190086

[8] Kanika, Singh, K., Rana, K., Dahiya, M. (2016). A comparative study on green and conventional buildings. International Journal of Home Science, 2(2): 338-343.

[9] USGBC. (2010). Green building design and construction. www.epa.gov/iaq/pubs/sbs.html, accessed on Dec. 23, 2020.

[10] UN-Habitat. (2018). Sustainable building finance: A practical guide to project financing in East Africa. United Nations Human Settlements Programme (UN-Habitat), Nairobi, Kenya. https://unhabitat.org/sites/default/files/2020/06/gh048e. pdf, accessed on Dec. 23, 2020.

[11] Aghimien, D. Aigbavboa, C.C. Ngcobo, C., Thwala, W. (2019). Barriers of sustainable construction practices in Nigeria. Proceedings of the 13th Built Environment Conference - Technology, Theory, Truth: Constructing a Sustainable Built Environment, Durban, South Africa.

[12] Aghimien, D., Aigbavboa, C., Thwala, W. (2019). Microscoping the challenges of sustainable construction in developing countries. Journal of Engineering, Design and Technology, 17(6): 1110-1128. https://doi.org/10.1108/JEDT-01-2019-0002

[13] Chan, A.P.C., Darko, A., Ameyaw, E.E. (2017). Strategies for promoting green building technologies adoption in the construction industry - an international $\begin{array}{llll}\text { study. } & \text { Sustainability, } & 969)\end{array}$ https://doi.org/10.3390/su9060969

[14] Daniel, E.I., Oshineye, O., Oshodi, O. (2018). Barriers to sustainable construction practice in Nigeria. In: Gorse, C., Neilson, C.J. (eds) Proceeding of the $34^{\text {th }}$ Annual ARCOM Conference, Belfast, UK, Association of Researchers in Construction Management, pp. 149-158. 
[15] Ismael, D., Shealy, T. (2018). Sustainable construction risk perceptions in the Kuwaiti construction industry. Sustainability, 10(6):
https://doi.org/10.3390//su10061854

[16] Javed, N., Thaheem, M.J., Bakhtawar, B., Nasir, A.R., Khan, K.I.A., Gabriel, H.F. (2020). Managing risk in green building projects: Toward a dedicated framework. Smart and Sustainable Built Environment, 9(2): 156-173. https://doi.org/10.1108/SASBE-11-2018-0060

[17] Ranaweera, R., Crawford, R.H. (2010). Using early stage assessment to reduce the financial risks and perceived barriers of sustainable buildings. Journal of Green Building, $5(2)$ :

129-146. https://doi.org/10.3992/jgb.5.2.129

[18] Susanti, B., Filestre, S.F.H., Juliantina, I. (2019). The analysis of barriers for implementation of sustainable construction in Indonesia. IOP Conference Series: Earth and Environmental Science, 396: 012033. https://doi.org/10.1088/1755-1315/396/1/012033

[19] Abisuga, A.O., Oyekanmi, O.O. (2014). Organizational factors affecting the usage of sustainable building materials in the Nigerian construction industry. Journal of Emerging Trends in Economics and Management Sciences (JETEMS), 5(2): 113-119.

[20] Maasz, R. (2019). Delivering sustainability throughout the project life cycle. http://constructorscompany.org.uk/wpcontent/uploads/2019/11/Sustainability-2017-18Maasz.pdf, accessed on Dec. 23, 2020.

[21] Elforgani, M.S., Rahmat, I. (2012). The influence of clients' qualities on green design performance of building projects in Malaysia-descriptive study. American Journal of Applied Sciences, 9(10): 1668-1677.

[22] Ryd, N. (2014). Construction clients challenges Emphasizing early stages. Procedia - Social and Behavioral Sciences, 119: 134-141. https://doi.org/10.1016/j.sbspro.2014.03.017

[23] Davies, O.O.A., Davies, I.O.E. (2017). Barriers to implementation of sustainable construction techniques. MAYFEB Journal of Environmental Science, 2: 1-9.

[24] Balasubramanian, S. (2020). Stakeholders' role in delivering sustainable supply chains in the construction sector. International Journal of Society Systems Science, 12(2):

$165-184$ https://doi.org/10.1504/IJSSS.2020.108415

[25] Alharthi, A., Soetanto, R., Edum-Fotwe, F.T. (2014). Revisiting client roles and capabilities in construction procurement. Proceedings of the International Conference on Construction in a Changing World- CIB W92 Procurement Systems, Sri Lanka, 12.

[26] Challender, J., Whitaker, R. (2019). The Client Role in Successful Construction Projects. Routledge, London. https://doi.org/10.1201/9781315164458

[27] Chigangacha, P.S., Haupt, T.C. (2017). Effectiveness of client involvement in construction projects: A contractor perspective. Proceedings of the 11th Built Environment Conference, Durban, South Africa, pp. 249-266.

[28] Constructing Excellence. (2004). Sustainable construction: clients. https://constructingexcellence.org.uk/wpcontent/uploads/2015/03/sus_clients.pdf, accessed on Dec. 23, 2020.

[29] Mashwama, X.N, Thwala, D.W., Aigbavboa, C.O. (2020). Obstacles of sustainable construction project management in South Africa construction industry. In: Scott, L., Dastbaz, M., Gorse, C. (eds) Sustainable Ecological Engineering Design. Springer, Cham, 305314. https://doi.org/10.1007/978-3-030-44381-8_23

[30] Ali, H.H., Alkayed, A.A. (2019). Constrains and barriers of implementing sustainability into architectural practices in Jordan. Alexandra Engineering Journal, 58(3):

1011-1023. https://doi.org/10.1016/j.aej.2019.09.003

[31] Amuda-Yusuf, G., Raheem W.M., Adebiyi, R.T., Abdulraheem, M.O., Idris, S., Eluwa, S.E. (2020). Barrier factors affecting adoption of green building technologies in Nigeria. Built Environment Journal, 17(2): 37-48. https://doi.org/10.24191/bej.v17i2.8860

[32] Chan, A.P.C., Darko, A., Olanipekun, A.O., Ameyaw, E.E. (2018). Critical barriers to green building technology adoption in developing countries: The case of Ghana. Journal of Cleaner Production, 172: 1067-1079. https://doi.org/10.1016/jclepro.2017.10.235

[33] Hoxha, V., Shala, F. (2019). The benefits and challenges of sustainable buildings in Prishtina, Kosovo. Facilities, 37(13/14): 1118-1152. https://doi.org/10.1108/F-082018-0097

[34] Ifije, O., Aigbavboa, C. (2020). Identifying barriers of sustainable construction: A Nigerian case study. MATEC Web of Conferences, 312: 04004. https://doi.org/10.1015/matecconf/202031204004

[35] Mohd-Rahim, F.A., Mohd-Yusoff, N.S., Chen, W., Zainon, N., Yusoff, S., Deraman, R. (2016). The challenge of labor shortage for sustainable construction. Planning Malaysia: Journal of the Malaysian Institute of Planners, $14(5)$ : 77-88. https://doi.org/10.21837/pmjournal.v14.i5.194

[36] Pham, H., Kim, S.Y., Luu, T.V. (2020). Managerial perceptions on barriers to sustainable construction in developing countries: Vietnam case. Environment, Development and Sustainability, 22(4): 2979-3003. https://doi.org/10.1007/s10668-019-00331-6

[37] Gunduz, M., Almuajebh, M. (2020). Critical success factors for sustainable construction project management. Sustainability, $\quad 12(5)$ : https://doi.org/10.3390/su12051990

[38] Hwang, B.G. Zhu, L., Tan, J.S.H. (2017). Green business park project management: Barriers and solutions for sustainable development. Journal of Cleaner Production, 153: https://doi.org/10.1016/j.jclepro.2017.03.210

209-219.

[39] Sarhan, J., Xia, B., Fawzia, S., Karim, A., Olanipekun, A. (2018). Barriers to implementing lean construction practices in the Kingdom of Saudi Arabia (KSA) construction industry. Construction Innovation, 18(2): 246-272. https://doi.org/10.1108/CI-04-2017-0033

[40] Wiafe, F. (2016). Factors affecting the implementation of sustainable construction in Ghana: the architect's perspective. MSc. Thesis Department of Building Technology, College of Art and Built Environment.

[41] Sourani, A., Sohail, M. (2013). Enabling sustainable construction in UK public procurement. Proceedings of the Institution of Civil Engineers - Management, Procurement and Law, 166(6): 297-312. http://dx.doi.org/10.1680/mpal.12.00022

[42] Berawi, M.A., Basten, V., Latief, Y., Crévits, I. (2020). Role of green building developer and owner in sustainability construction: Investigating the 
relationships between green building key success factors and incentives. IOP Conference Series: Earth and Environmental Science, 426: 012061. https://doi.org/10.1088/1755-1315/426/1/012061

[43] Ofori, G. (2007). Clients' role in attainment of sustainability in housing: The case of Singapore and lessons for developing countries. Journal of Construction in Developing Countries, 12(2): 1-3.

[44] Saleh, M.S., Alalouch, C. (2015). Towards sustainable construction in Oman: Challenges \& opportunities. Procedia Engineering, 118: 177-184. https://doi.org/10.1016/j.proeng.2015.08.416

[45] Fauzi, S.N.F.M., Yusof, N.A., Awang, H., Nah, M.N.N. (2018). Factors influencing engineers' attitude towards environmental sustainability. E3S Web of Conferences (ICCEE 2018), 65: 04003 . https://doi.org/10.1051/e3sconf/20186504003

[46] Ametepey, O., Aigbavboa, C., Ansah, K. (2015). Barriers to successful implementation of sustainable construction in the Ghanaian construction industry. Procedia Manufacturing, 3: 1682-1689. https://doi.org/10.1016/j.promfg.2015.07.988

[47] Angonese, R., Lavarda, C.E.F. (2014). Analysis of the factors affecting resistance to change in management accounting systems. Revista Contabilidade \& Finanças, 25(66): 214-227. https://doi.org/10.1590/1808$057 \times 201410810$

[48] Djokoto, S.D., Dadzie, J., Ohemeng-Ababio, E. (2014). Barriers to sustainable construction in the Ghanaian construction industry: Consultants' perspectives. Journal of Sustainable Development, 7(1): 134-143. https://doi.org/10.5539/jsdv7n1p134

[49] Lee, K.H., Ahn, Y.H., Jeon, M., Suh, M.J. (2014). Organizational strategies to support sustainability in the construction company. In the World SB14, Barcelona, Spain, pp. 1-9.

[50] Schweiger, S., Stouten, H., Bleijenbergh, I.L. (2018). A system dynamics model of resistance to organizational change: The role of participatory strategies. System Research and Behavioral Science, 35(6): 658-674. https://doi.org/10.1002/sres.2509

[51] Aghimien, D., Aigbavboa, C., Oke, A., Musenga, C. (2018). Barriers to sustainable construction practices in the Zambian construction industry. Proceedings of the International Conference on Industrial Engineering and Operations Management, Paris, France, pp. 2383-2392.

[52] Damawan, A.H., Azizah, S. (2020). Resistance to change: Causes and strategies as an organizational challenge. Advances in Social Science, Education and Humanities Research, 395: 49-53. https://doi.org/10.2991/assehr.k.200120.010

[53] Khan, K., ur Rehman, M. (2008). Employees resistance towards organizational change. MSc. Thesis in Business Administration, Blekinge Institute of Technology School of Management Ronneby, Sweden.

[54] Abolore, A.A. (2012). Comparative study of environmental sustainability in building construction in Nigeria and Malaysia. Journal of Emerging Trends in Economics and Management Sciences (JETEMS), 3(6): 951-961.

[55] Esezobor, E.L. (2016). Sustainability and construction: A study of the transition to sustainable construction practices in Nigeria. PhD Dissertation, Birmingham City University, UK.
[56] Khan, M.M., Raza, M.A., Mujtaba, B.G. (2016). Determinants of resistance to organizational change: A qualitative study of a non-governmental organization in Pakistan. Journal of Educational Leadership and Policy, 1(3): 43-50.

[57] Cardoso, L., Araujo, N., Brea, J.A.F., Dieguez-Soto, J. (2019). Benefits and risks of green jobs in the construction industry. Journal of Scientific and Industrial Research, 78(3): 254-157.

[58] Fortunate III, B.R., Hallowell, M.R., Behm, M., Dewlaney, K. (2012). Identification of safety risks for high-performance sustainable construction projects. Journal of Construction Engineering and Management, 138(4): 499-508. https://doi.org/10.1061/(ASCE)CO.1943-7862.0000446

[59] Kasapoğlu, E. (2018). Risk management in construction. In: Almusaed, A. (ed) Sustainable Buildings Interaction between a Holistic Conceptual Act and Materials Properties. London, UK, IntechOpen. https://doi.org/10.5772/intechopen.76341

[60] Onubi, H.O., Yusof, N., Hassan, A.S. (2019). Adopting green construction practices: Health and safety implications. Journal of Engineering, Design and Technology, 18(3): 635-652. https://doi.org/10.1108/JEDT-08-2019-0203

[61] Paradis, R., Tran, B. (2016). Balancing security/safety and sustainability objectives. National Institute of Building Sciences, Washington. https://www.wbdg.org/resources//balancing-

securitysafety-and-sustainability-objectives, accessed on Dec. 23, 2020.

[62] Zhao, X. Hwang, B.G., Gao, Y. (2016). A fuzzy synthetic evaluation approach for risk assessment: A case of Singapore's green projects. Journal of Cleaner Production, 115: 203-213. https://doi.org/10.1016/j.clepro.2020.120372

[63] Zou, P.X.W., Couani, P. (2012). Managing risks in green building supply chain. Architectural Engineering and Design Management, 8(2): 143-158. https://doi.org/10.1080/17452007.2012.659507

[64] Pham, H., Kim, S.Y., Luu, T.V. (2019). Managerial perceptions on barriers to sustainable construction in developing countries: Vietnam case. Environment, Development and Sustainability, 2: 1-25. https://doi.org/10.1007/s10668-019-00331-6

[65] Macrì, D.M., Tagliaventi, M.R., Bertolotti, F. (2002). A grounded theory for resistance to change in a small organization. Journal of Organizational Change Management, $15(3)$ : 292-310. https://doi.org/10.1108/09534810210429327

[66] Omopariola, E.D., Albert, I., Windapo, A. (2019). Appropriate drivers for sustainable construction practices on construction sites in Nigeria. In: Laryea, S., Essah, E. (Eds) Proceedings of the 10th West Africa Built Environment Research (WABER) Conference, 5-7 August 2019, Accra, Ghana, 103-115. https://doi.org/10.33796/waberconference2019.07

[67] Shen, L., Tam, V.W.Y., Tam, L., Ji, Y. (2010). Project feasibility study: The key to successful implementation of sustainable and socially responsible construction management practice. Journal of Cleaner Production, 18(3): 254-259. http://dx.doi.org/10.1016/j.jclepro.2009.10.014

[68] Tunji-Olayeni, P., Kajimo-Shakantu, K., Osunrayi, E. 
(2020). Practitioners' experiences with the drivers and practices for implementing sustainable construction in Nigeria: A qualitative assessment. Smart and Sustainable Built Environment, 9(4): 443-465. https://doi.org/10.1108/SASBE-11-2019-0146

[69] Ybema, S., Thomas, R., Hardy, C. (2016). Organizational change and resistance: An identity perspective. In: Courpasson, D., Valles, S. (eds), The Sage Handbook of Resistance, Sage Publications, London, England, pp. 386-404.

[70] Langstrand, J., Elg, M. (2012). Non-human resistance in changes towards lean. Journal of Organizational Change Management, 25(6): 853-866. https://doi.org/10.1108/09534811211280609

[71] Darko, A., Chan, A.P.C. (2017). Review of barriers to green building adoption. Sustainable Development, 25(3): 167-179. https://doi.org/10.1002/sd.1651

[72] Lam, P.T.I., Chan, E.H.W., Poon, C.S., Chau, C.K., Chun, K.P. (2010). Factors affecting the implementation of green specifications in construction. Journal of Environmental Management, 91(3): 654-661. https://doi.org/10.1016/j.jenvman.2009.09.029

[73] Akadiri, O.P. (2011). Development of a multi-criteria approach for the selection of sustainable materials for building projects. $\mathrm{PhD}$ Thesis, University of Wolverhampton, Wolverhampton, UK.

[74] Enshassi, A., Al Ghouland, H., Alkilani, S. (2018).
Exploring sustainable factors during construction projects' life cycle phases. Revista Ingeniería de Construcción, 33(1): 51-68. http://dx.doi.org/10.4067/S0718-50732018000100051

[75] Okoye, P.U., Odesola, I.A., Okolie, K.C. (2020). Evaluating the importance of construction activities for sustainable construction practices in building projects in Nigeria. Journal of Sustainable Construction Materials and Technologies, 5(2): 430-439. https://doi.org/10.29187/jscmt.2020.47

[76] Yang, X., Zhang, J., Zhao, X. (2018). Factors affecting green residential building development: Social network $\begin{array}{llll}\text { analysis. } & \text { Sustainability, } & 10(5) \text { : } & 1389 .\end{array}$ https://doi.org/10.3390/su10051389

[77] Gould, F., Joyce, N. (2014). Construction Project Management (4th Ed). Pearson Education, Boston.

[78] Masterman, J.W.E. (2002). An Introduction to Building Procurement Systems (6th Ed). Spon Press, London.

[79] Ekolu, S.O., Quainoo, H. (2019). Reliability of assessment in engineering education using Cronbach's alpha, KR and split-half methods. Global Journal of Engineering Education, 21(1): 24-29.

[80] Tavakol, M., Dennick, R. (2011). Making sense of Cronbach's alpha. International Journal of Medical Education, $\quad$ Editorial, 2 53-55. https://doi.org/10.5116/ijme.4dfb.8dfd 